\title{
Use of Medicinal and Aromatic Plants in Therapeutic Gardens
}

\author{
Mükerrem Arslan', Zeynep Kalaylioglu ${ }^{1,2}$, Erdi Ekren ${ }^{1 *}$ \\ ${ }^{1}$ Department of Landscape Architecture, Faculty of Agriculture, Ankara University, Ankara, TURKEY. \\ ${ }^{2}$ Department of Statistics, Faculty of Arts and Sciences, Middle East Technical University, Ankara, TURKEY.
}

\begin{abstract}
Introduction: Today there is an accumulation of literature providing evidence for long and short term beneficial effects of living close to nature on various different health conditions ranging from psychological to physical disorders including depression, heart problems and diabetes. The results of these researches have given rise to the promotion of therapeutic gardens in outdoor spaces of healthcare establishments such as children's hospitals, assisted-living houses, rehabilitation centers, and hospices. Objective: Therapeutic gardens are outdoor garden spaces that meet the needs of the users mainly for their psychological well-being and healing. Our focus in this study is the use and maintenance of medicinal and aromatic plants in therapeutic gardens. Our objectives are to review the literature on this topic, categorize the role of medicinal and aromatic plants as a design element, and provide medicinal and aromatic plants design guidelines for therapeutic gardens. Methods: Entire literature on the topic are reviewed. A sense-system used to categorize medicinal and aromatic plants for therapeutic gardens with respect to the purpose of garden use. Results and Discussion: Design guidelines are created to aid the planning of medicinal and aromatic plants in therapeutic gardens. Conclusion: Consequently, it is given that aromatic plants are a good attempt to improve the healing environment of therapeutic gardens from an aesthetic as well as medicinal standpoint and our design guidelines provide the landscape designer with essential ingredients to efficiently incorporate medicinal and aromatic plants in designing therapeutic gardens.
\end{abstract}

Key words: Healing garden, Health facilities, Stress, Assisted-living house, Planting design.

\section{INTRODUCTION}

The plants that have both odor and taste characteristics and are used as pharmaceutical raw materials are called "medicinal and aromatic plants". These plants are used as ornamental plants in plant design studies because they are decorative as well as spice, food, herb tea use and therapeutic properties. ${ }^{1-2}$

People used plants for various purposes throughout the history such as food, warming, defense, tapping their feelings, and most importantly finding healing. As the ages progressed, with the development of medicinal science, the importance of medicinal and aromatic plants used for the purpose of healing has also increased and it has become a big market that deals with various profes- sions. Medicinal and aromatic plants are used for functional and aesthetic purposes in urban design studies as well. They can be used in areas such as collection gardens, healing gardens, therapy gardens, botanical gardens, rock gardens, dry stone walls, parterres, flowerpots, roof and terrace gardens, sloping areas and roads. ${ }^{2}$

The determination of the natural environment and designed spaces to play an important role in accelerating the healing period has been a factor in transforming the gardens into health care spaces. ${ }^{3}$ Therapy gardens are designed spaces that are widely used in this field. Therapy gardens are designed to reduce the pain and stress besides that
Submission Date: 23-06-17 Revision Date: 22-06-18; Accepted Date: 28-06-18.

DOI: 10.5530/ijper.52.4s.92 Correspondence:

Erdi Ekren,

${ }^{1}$ Department of Landscape Architecture, Faculty of Agriculture, Ankara University, Ankara, TURKEY.

Phone: +90 3125961516

E-mail: ekren@ankara.edu.tr

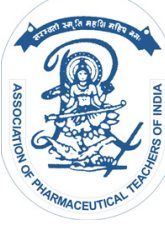

www.ijper.org 
physically, mentally and spiritually strengthening patients who have physical or psychological problems. Medicinal and aromatic plants have very important functions in these gardens in terms of aesthetics and functionality. ${ }^{4}$ Medicinal and aromatic plants and a variety of activities stimulate the senses of those who use the garden. For example; with pleasant smelling plants that bloom in different seasons the sense of smell, with plants that have different tissues the sense of touch, with plants that have aesthetically valuable leaves, flowers and fruits the sense of sight is stimulated. Besides, the collection and taste of the cultivated products stimulate the sense of taste.

Our aims in this study are:

1. To determine some of the general rules that should be considered when selecting plant species in therapy gardens and the features that cause medicinal and aromatic plants used in these gardens,

2. To specify the principles that should be considered in therapy gardens' plant design works.

\section{MATERIALS AND METHODS}

The emergence of the concept of therapy garden, its historical development, its philosophy and areas of use of therapy gardens are examined first. Later, the plant design phase, which is an important design stage of the therapy gardens, has been dealt with. The general properties that must be found in the plants to be used in the therapy gardens and general rules that must be followed in plant design of therapy garden are given. The importance of medicinal and aromatic plants for therapy gardens has been explored and given. Important medicinal and aromatic plants that are used in therapy gardens have been identified and the characteristics of these species in terms of their use in therapy gardens have been explained.

\section{RESULTS AND DISCUSSIONS}

\section{A Brief Overview on Health and Garden}

Today, there are many scientific sources about the positive effects of living close to nature on adult and child health. These studies reveal the short and long term effects of living close to nature on our psychological and physiological health. Ulrich (1984), found that 23 patients in the room with a window with a natural landscape view resulted in a reduction in their post-operative complaints, hospital stay, and pain relief use compared to 23 patients who were matched in a room with windows overlooking a brick building wall. ${ }^{5}$ Therapy gardens are very important for sick and / or older people to parti- cipate more effectively in social life. Therapy gardens can be designed in nursing homes, hospitals, health care centers, prisons, child dormitories and also in urban open green spaces. However, these gardens need to be created within the framework of design criteria in order to create the desired effect on user groups and to be sustainable.

\section{Therapy Garden Design}

Therapy gardens have differences in their design according to the age groups they address and their disease state. For example; silence and calmness will be essential in a therapy garden which designed for elderly, while a therapy garden designed for the children is based on freedom of play and exploring new things. ${ }^{6}$ One of the most important steps in the design of therapy gardens is the plant design phase to be carried out with medicinal and aromatic plants in the garden. According to Lewis (1996), bringing plants into the conceptual level can be achieved because plants can be identified by characteristics such as size, shape, color, and weight. ${ }^{7-8}$

Good planting design works rely on the designer's understanding of the different roles that plants play. ${ }^{8}$ Just as in all landscape design studies, in plant design of therapy gardens, firstly the effect desired to be created with plants is decided and appropriate plant species should be determined in this direction. In addition, there are some general rules that must be observed in the selection of plant species in therapy gardens.

According to Chalfont (2008), plants for horticultural therapy can be chosen that:

- are non-poisonous,

- are multi-dimensional with uses such as culinary and crafts,

- have a distinctive color, shape and texture,

- are easy to propagate and grow,

- provide sensory stimulation,

- stimulate memory and creativity, and

- $\quad$ provide meaningful activity. ${ }^{9}$

Plant design works in therapy gardens have differences according to the age groups they address and their disease state but they have also some general principles. These plant design principles can be listed as follows;

- You should be ensured that planting design and material provide a rich, multisensory experience (color/texture combinations, fragrance and wildlife habitat), ${ }^{10}$

- To create a safe garden, garden boundaries must be identified with plants, ${ }^{8}$ 


\begin{tabular}{|c|c|c|c|}
\hline \multicolumn{2}{|c|}{ Table 1: Some of the medicinal and aromatic plant species in the garden and their characteristics. ${ }^{11-12}$} \\
\hline Scientefic Name & Flower Color & Bloom Time & Notes \\
\hline Allium schoenoprasum L. & Pink & April to May & Fragrant Leaves \\
\hline Artemisia abrotanum L. & Yellowish-white & August to October & Fragrant Leaves \\
\hline Cerastium tomentosum L. & White & June & Fragrant Leaves \\
\hline Foeniculum vulgare Mill. & Yellow & June to July & Fragrant Leaves \\
\hline Melissa officinalis L. & White to pale yellow & June to August & Fragrant Leaves \\
\hline Lavandula vera DC. & Purple & June to August & Fragrant leaves and flowers \\
\hline Mentha aquatica var. crispa (L.) Benth & Silver & July to August & Fragrant Leaves \\
\hline Monarda "Squaw" & Red & July to September & Fragrant Leaves \\
\hline Pelargonium crispum (P.J. Bergius) L'Hér & Pink to white & Seasonal bloomer & Evergreen, Fragrant Leaves \\
\hline Thymus citriodorus (Pers) Schreb & Pale lilac & July & Fragrant Leaves \\
\hline Asarum europaeum L. & Greenish-yellow to brown & April to May & Fragrant Leaves \\
\hline Asarum shuttleworthii Britten and Bakerf. & Purplish brown & April to May & Fragrant Leaves \\
\hline
\end{tabular}

- Using color cues and color codes in the therapy gardens could improve orientation and enhance the quality of care, ${ }^{8}$

- Given the seasonal characteristics of the plants to be used in the garden, the garden must be kept effective throughout the four seasons, ${ }^{8}$

- The therapy garden, where the plant design practice will be performed, must be perceived by a person inside the building. It should be considered that views of the garden from more than one location, ${ }^{10}$

- Incorporate planting that offers fascination and sensory engagement such as ornamental grasses, ${ }^{10}$

- Utilize plant material to shape space within the garden by creating subspaces, canopies, and privacy screening, ${ }^{10}$

- Generally, low maintenance and resilient plants should be used in the garden, ${ }^{10}$

- Natural plant species should be utilized to provide the sustainability of the garden and to minimize the risk of failure, ${ }^{10}$

- Approximately half of the patio area needs to be designed to supply varying degrees of shade by using plants, ${ }^{8}$

- $\quad$ Raised plant beds will make it easier for disabled and non-disabled users to reach plants. ${ }^{8}$

\section{Medicinal and Aromatic Plants in Therapy Garden Design}

The study examined a sensory garden in the United States and introduced medicinal and aromatic species in this garden.

The sensory garden established in the "Westminster Village Nursing Home" in the US state of Indiana, which provides care for people with Alzheimer's disease, is helping patients cope with the disease they are strug- gling by activating their senses. The flower beds created for this sensory garden are also positioned at an appropriate height for wheelchair users. The plants to be used in the garden are species selected according to their color, smell and texture. Some of the medicinal and aromatic plant species in the garden and their characteristics are shown in Table $1 .{ }^{11}$

\section{CONCLUSION}

Medicinal and aromatic plants today have a very important place in the aesthetic and functional aspects of plant design studies with leaf forms in different colors and textures and flowers in different shape and colors. Contrary to other landscape works, plants used in therapy gardens should provide sensory, memory and creativity stimulation. In this context, choosing the right plant species for the purpose of use and placing them in the direction of the desired effect are the main factors affecting the success of plant design.

\section{CONFLICT OF INTEREST}

The authors declare no conflict of interest.

\section{REFERENCES}

1. Missouri Botanical Garden. [homepage on the Internet]. [cited 2017 Feb 20]. Available from: http://www.missouribotanicalgarden.org/,

2. Arslan M. Tıbbi ve Aromatik Bitki Türlerinin Peyzaj Mimarlığı Çalışmalarında Kullanım Olanakları, IV. Süs Bitkileri Kongresi. 2010:20-22.

3. Arslan M, Katipoğlu E. Kentsel Çevrede Yaşlı Kişilerin Sağlığı ve Etkinlikler İçin Bitki Yetiştiriciliğinin Önemi. Yaşlı Sorunları Araştırma Dergisi. 2011; 4(1-2):44-52.

4. Arslan M, Peng M. Taiwan ve Türkiye'de Tıbbi ve Aromatik Bitki Türlerinin Kullanımı. V. Süs Bitkileri Kongresi. 2013.

5. Chalfont G. Design for Nature in Dementia Care, London. Jessica Kingsley Publishers. 2007 
6. Erbaş S. Türkiye'nin Bazı Tıbbi ve Aromatik Bitkileri, Doğa Koruma ve Milli Parklar Genel Müdürlüğü e-kitap. 2013;36.

7. Lewis CA. Green Nature/ Human Nature: The Meaning of Plants in Our Lives. University of Illinois Press. 1996.

8. Marcus CC, Sachs NA. Therapeutic Landscapes: An Evidence-Based Approach to Designing Healing Gardens and Restorative Outdoor Spaces. John Wiley and Sons, editors. 2014:261-87.

9. Mei C. Planting Design and Its Impact On Efficacy In Therapeutic Garden Design For Dementia Patients In Long-Term Care Facilities In North Texas. The University of Texas at Arlington, Department of Landscape Architecture, Master Thesis. 2012.
10. Palasinski CE. Life with Fading Memories: Links to the Past for Westminster Village Residents through a Therapeutic Garden Courtyard. Ball State University, Department of Landscape Architecture, $5^{\text {th }}$ Year Comprehensive Project. 2002:57-8.

11. Predny ML. Assessing an Intergenerational Horticulture Therapy Program for Elderly Adults And Preschool Children. Faculty of Virginia Polytechnic Institute and State University, Horticulture Department, Master Thesis. 1999.

12. Ulrich RS. View through a Window May Influence Recovery from Surgery. Science. New Series. 1984;224(4647):420-1.

\section{PICTORIAL ABSTRACT}

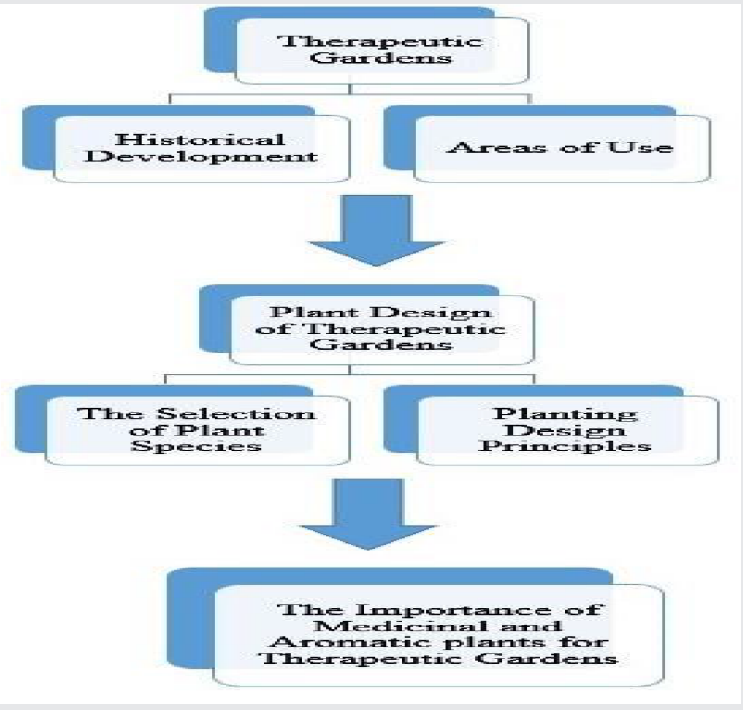

\section{ABOUT AUTHORS}

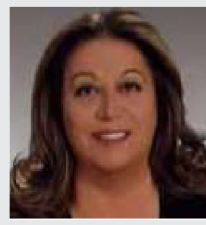

Mukerrem Arslan: Is presently working as Professor in Department of Landscape Architecture in Ankara University. She has experience in the area of planting design, landscape and greenway planning, ornamental plants and theme parks.

\section{SUMMARY}

- The plants that have both odor and taste characteristics and are used as pharmaceutical raw materials are called "medicinal and aromatic plants".

- These plants are used as ornamental plants in plant design studies because they are decorative as well as spice, food, herb tea use and therapeutic properties.

- Therapy gardens are designed to reduce the pain and stress besides that physically, mentally and spiritually strengthening patients who have physical or psychological problems.

- Medicinal and aromatic plants have very important functions in these gardens in terms of aesthetics and functionality. Medicinal and aromatic plants and a variety of activities stimulate the senses of those who use the garden.

- Therapy gardens need to be created within the framework of design criteria in order to create the desired effect on user groups and to be sustainable. These gardens have differences in their design according to the age groups they address and their disease state.

- Planting design works in therapy gardens have differences according to the age groups they address and their disease state but they have also some general principles.

- In this context, choosing the right plant species for the purpose of use and placing them in the direction of the desired effect are the main factors affecting the success of planting design.



Zeynep Kalaylioglu: Is currently Associate Professor of Statistics at the Department of Statistics, Middle East Technical University (METU), Ankara, Turkey. She earned her Ph.D. in Statistics at North Carolina State University, USA, in 2002. She was working towards a master degree in Landscape Architecture at Ankara University under the supervision of Prof. Arslan during the research presented here.

Erdi Ekren: Is presently working as Research Assistant in Department of Landscape Architecture in Ankara University. He has experience in the area of ornamental plants, environmental sustainability and vertical gardens.

Cite this article: Arslan M, Kalaylioglu Z, Ekren E. Use of Medicinal and Aromatic Plants in Therapeutic Gardens. Indian J of Pharmaceutical Education and Research. 2018;51(4S):S151-S154. 